\title{
Penerapan Teorema Bayes Untuk Mendiagnosa Penyakit yang Diakibatkan oleh Bakteri Treponema Pallidum
}

\author{
Nita Sari Br Sembiring \\ Program Studi Sistem Informasi Universitas Potensi Utama \\ E-mail : nita.sembiring86@ gmail.com
}

\begin{abstract}
Abstrak
Bakteri treponema pallidum merupakan suatu bakteri yang dapat menyebabkan penyakit sifilis. Bakteri Treponema Pallidum dapat ditularkan melalui kontak fisik seperti hubungan seksual sehingga mengakibatkan korban terkena penyakit sifilis. Biasanya hanya sedikit penularan melalui kontak bibir, melalui jarum suntik, atau penularan melalui ibu yang mengidap sifilis tiga tahun pertama ke janinnya. Permasalahan yang sering dihadapi oleh masyarakat dari bakteri ini ialah ketidaktahuan masyarakat akan gejala dan penyakit yang diakibatkan oleh bakteri treponema pallidum ini serta proses penyebaran dari bakteri Treponema Pallidum ini. Masyarakat juga banyak yang belum mengetahui bagaimana cara untuk menangani secara dini jika sudah terkena penyakit yang diakibatkan oleh bakteri ini. Pada proses diagnosa dari bakteri Treponema Pallidum ini diperlukan suatu metode probabilitas untuk dapat memberikan tingkat kepercayaan dari hasil diagnosa. Teorema bayes dapat digunakan sebagai metode untuk menentukan tingkat probabilitas dari hasil diagnosa penyakit yang diakibatkan oleh bakteri Treponema Pallidum. Hasil dari penelitian ini ialah mendiagnosa penyakit yang diakibatkan oleh bakteri Treponema Pallidum dengan menggunakan Teorema Bayes.
\end{abstract}

Kata Kunci: Teorema Bayes, Bakteri Treponema Pallidum, Sifilis.

\begin{abstract}
Treponema pallidum is a bacterium that can cause syphilis. Treponema pallidum bacteria can be transmitted through physical contact such as sexual intercourse so that the victim is exposed to syphilis. Usually there is very little transmission through lip contact, through needles, or transmission from a mother who has syphilis in the first three years to her fetus. The problem that is often faced by the community from this bacterium is the public's ignorance of the symptoms and diseases caused by the Treponema pallidum bacteria and the process of spreading this Treponema pallidum bacteria. Many people also do not know how to treat it early if it is already exposed to a disease caused by this bacterium. In the process of diagnosis of Treponema pallidum bacteria, a probability method is needed to be able to provide a level of confidence in the diagnostic results. Bayes theorem can be used as a method to determine the probability level of the diagnosis of diseases caused by the bacterium Treponema pallidum. The result of this study is to diagnose diseases caused by Treponema pallidum bacteria using Bayes' Theorem.
\end{abstract}

Keywords: Bayes Theorem, Treponema Pallidum Bacteria, Syphilis. 


\section{PENDAHULUAN}

Sifilis ialah penyakit infeksi yang disebabkan oleh Treponema pallidum, sangat kronik dan bersifat sistematik. Sifilis dapat menyerang hampir semua bagian tubuh, dapat menyerupai banyak penyakit, mempunyai massa laten, dan dapat di tularkan dari ibu ke janin [1][2][3].

Bakteri Treponema Pallidum berbentuk spiral teratur, panjangnya antara 6-15 um, lebar 0,15 um, terdiri atas delapan sampai dua puluh empat lekukan. Gerakannya berupa rotasi sepanjang aksis dan maju seperti gerakan pembuka botol. Berkembang secara pembelahan melintang, pada stadium aktif terjadi setiap tiga puluh jam. Pembiakan pada umumnya tidak dapat dilakukan di luar badan kuman tersebut cepat mati, sedangkan dalam darah untuk transfusi dapat hidup tujuh puluh dua jam [2].

Bakteri Treponema Pallidum dapat ditularkan melalui kontak fisik seperti hubungan seksual sehingga mengakibatkan korban terkena penyakit sifilis. Biasanya hanya sedikit penularan melalui kontak bibir, melalui jarum suntik, atau penularan melalui ibu yang mengidap sifilis tiga tahun pertama ke janinnya [3][4].

Penyakit sifilis yang parah dapat berujung pada komplikasi. Perubahan perilaku dapat memicu meningkatnya kasus sifilis. Perubahan perilaku tersebut dapat dipengaruhi oleh budaya, social maupun teknologi modern yang ada di dunia ini. Selain perubahan perilaku, perubahan karakteristik bakteri Treponema pallidum itu sendiri juga dapat meningkatkan kasus sifilis [5].

Permasalahan yang sering dihadapi oleh masyarakat dari bakteri ini ialah ketidaktahuan masyarakat akan gejala dan penyakit yang diakibatkan oleh bakteri treponema pallidum ini serta proses penyebaran dari bakteri Treponema Pallidum ini. Masyarakat juga banyak yang belum mengetahui bagaimana cara untuk menangani secara dini jika sudah terkena penyakit yang diakibatkan oleh bakteri ini.

Pada proses diagnosa dari bakteri Treponema Pallidum ini diperlukan suatu metode probabilitas untuk dapat memberikan tingkat kepercayaan dari hasil diagnosa. Teorema bayes dapat digunakan sebagai metode untuk menentukan tingkat probabilitas dari hasil diagnosa penyakit yang diakibatkan oleh bakteri Treponema Pallidum.

Teorema Bayes adalah teorema yang digunakan untuk menghitung peluang dalam suatu hipotesis. Bayes mencari fakta keberadaan tuhan didunia kemudian mengubahnya dengan nilai Probabilitas yang akan dibandingkan dengan nilai Probabilitas. teorema ini juga merupakan dasar dari statistika Bayes yang memiliki penerapan dalam ilmu ekonomi mikro, sains, teori permainan, hukum dan kedokteran [6][7].

Penelitian yang dilakukan oleh Sianturi pada tahun 2019 dengan judul penelitian "Analisa Metode Teorema Bayes Dalam Mendiagnosa Keguguran Pada Ibu Hamil Berdasarkan Jenis Makanan", menghasilkan kesimpulan yaitu teorema bayes dapat digunakan untuk mendiagnosa keguguran pada ibu hamil melalui jenis makanan yang dikonsumsinya [8].

Penelitian yang dilakukan oleh Ramadhan dan Tugiono pada tahun 2019 dengan judul penelitian "Sistem E-Pediatric Untuk Pendiagnosaan Eflorsen Dermatis Menggunakan Teorema Bayes", mengatakan bahwa teorema bayes telah berhasil mengomtimalkan hasil diagnosa serta penerapan Sistem Pakar ke dalam bentuk layanan diagnosa dengan menanamkan proses atau tahapan yang ada, sehingga telah dapat digunakan oleh masyarakat luas untuk mengidentifikasi atau menanggulangi permasalahan tentang Eflorsen Dermatis [9].

Penelitian yang dilakukan oleh Bangun dan Sagala pada tahun 2019 dengan judul penelitian "Sistem Pakar Mendiagnosa Penyakit Tbc Menggunakan Metode Teorema Bayes", mengatakan bahwa teorema bayes dapat digunakan sebagai metode probabilitas untuk 
mendiagnosa penyakit TBC [10].

Penelitian yang dilakukan oleh Rachman dan Moritami pada tahun 2020 dengan judul penelitian "Sistem Pakar Deteksi Penyakit Refraksi Mata Dengan Metode Teorema Bayes Berbasis Web", menghasilkan kesimpulan bahwa teorema bayes dapat diterapkan dalam sistem pakar yang dapat mendiagnosa penyakit refraksi mata. Teorema bayes dapat memberikan nilai probabilitas yang kuat untuk mendiagnos penyakit refraksi mata berdasarkan gejala yang dialami [11].

Penelitian yang dilakukan oleh Rosmawati dan Gusti pada tahun 2020 dengan judul penelitian "Model Sistem Pakar Diagnosa Penyakit Gagal Ginjal Menggunakan Metode Teorema Bayes", menghasilkan kesimpulan bahwa teorema bayes kurang baik digunakan untuk mendiagnosa penyakit gagal ginjal karena dari 20 kasus uji coba yang melibatkan pakar dan aplikasi hanya memperoleh tingkat akurasi sebesar 65\% [7]. Dimana berdasarkan tabel probabilitas teorema bayes nilai ini hanya menghasilkan keputusan "Kemungkinan Besar".

Hasil dari penelitian ini ialah menggunakan teorema bayes untuk melakukan diagnosa terhadap penyakit yang diakibatkan oleh bakteri treponema pallidum. Penelitian ini juga bertujuan untuk memberikan tambahan pengetahuan kepada masyarakat tentang penyakit yang dapat diakibatkan oleh bakteri treponema pallidum.

\section{METODE PENELITIAN}

Metode penelitian yang digunakan dalam penelitian ini adalah metode analisis deskriptif yaitu suatu metode yang bertujuan untuk mendapatkan gambaran yang jelas tentang hal-hal yang diperlukan melalui beberapa tahapan. Tahapan-tahapan tersebut akan dijabarkan secara detail sehingga penelitian yang dilakukan akan memperoleh hasil yang maksimal. Tahapan ini akan dimulai dari identifikasi masalah, analisis masalah, menentukan tujuan, metode pengumpulan data, hingga metode perhitungan probabilitas hasil diagnosa untuk memperoleh hasil perhitungan yang akurat. Adapun tahapan-tahapan yang dilakukan dalam penelitian ini dapat dilihat pada gambar 1 sebagai berikut. 


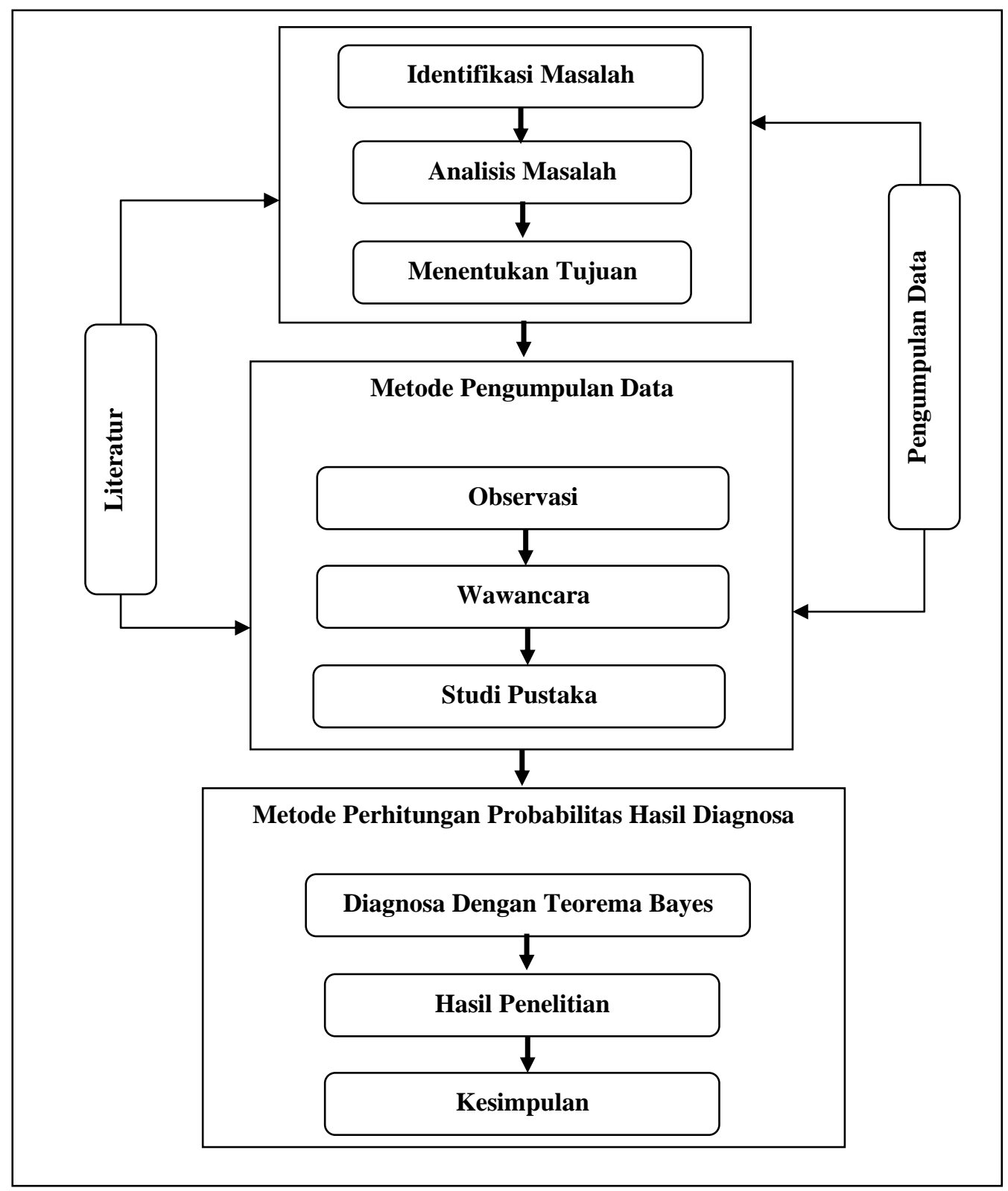

Gambar 1. Tahapan Penelitian

Penjelasan dari gambar 1 adalah sebagai berikut:

1. Identifikasi Masalah

Identifikasi masalah didefinisikan sebagai upaya untuk menjelaskan masalah dan membuat penjelasan dapat diukur. Identifikasi ini dilakukan sebagai langkah awal penelitian. Pada tahapan ini, peneliti mendefinisikan masalah yang telah ditemukan. Masalah yang telah ditemukan pada penelitian ini ialah bagaimana mendiagnosa penyakit yang diakibatkan oleh bakteri treponema pallidum dengan teorema bayes.

2. Analisis Masalah

Analisis masalah adalah kajian sementara untuk mengetahui penyebab timbulnya masalah serta alternatif pemecahan masalah tersebut. Pada tahapan ini, peneliti menganalisis masalah yang telah diidentifikasi. Peneliti akan mencari factor-faktor penyebab masalah 
tersebut timbul, menentukan gejala-gejala dari penyakit, dan diagnosa penyakit dengan teorema bayes.

3. Menentukan Tujuan

Pada tahap ini, peneliti menentukan target dan tujuan yang ingin dicapai. Dalam hal ini tujuan yang ingin dicapai ialah mengetahui hasil diagnosa penyakit yang diakibatkan oleh bakteri Treponema Pallidum dengan Teorema Bayes.

4. Metode Pengumpulan Data

Teknik pengumpulan data merupakan teknik-teknik yang dilakukan untuk memperoleh data dan keterangan-keterangan yang diperlukan dalam penelitian [11]. Pada penelitian ini, peneliti menggunakan metode pengumpulan data sebagai berikut:

a. Observasi

Peneliti melakukan pengamatan secara langsung ke klinik tempat pengobatan penyakit yang diakibatkan oleh bakteri Treponema Pallidum.

b. Wawancara

Peneliti melakukan wawancara secara langsung kepada pakar atau dokter tentang penyakit yang diakibatkan oleh bakteri Treponema Pallidum ini.

c. Studi Literatur

Peneliti melakukan riset pustaka melalui buku dan jurnal yang relevan dengan penelitian yang sedang dilakukan.

5. Metode Perhitungan Probabilitas Hasil Diagnosa

Pada penelitian ini, peneliti menggunakan teorema bayes untuk menghitung nilai probabilitas hasil diagnose penyakit. Teorema bayes merupakan metode yang baik di dalam mesin pembelajaran berdasarkan data training, dengan menggunakan probabilitas bersyarat sebagai dasarnya [6][7].

Teorema bayes merupakan metode yang baik di dalam mesin pembelajaran berdasarkan data training, dengan menggunakan probabilitas bersyarat sebagai dasarnya. Metode bayes juga merupakan suatu metode untuk menghasilkan estimasi parameter dengan menggabungkan informasi dari sampel dan informasi lain yang telah tersedia sebelumnya [10].

Teorema Bayes adalah cara untuk mengetahui probabilitas bersyarat. Probabilitas bersyarat adalah probabilitas dari suatu peristiwa yang terjadi, mengingat bahwa itu memiliki beberapa hubungan dengan satu atau lebih peristiwa lainnya [11].

Teorema bayes juga merupakan suatu metode untuk menghasilkan estimasi parameter dengan menggabungkan informasi dari sampel dan informasi lain yang telah tersedia sebelumnya [10][12]. Teorema Bayes merupakan salah satu cara yang baik untuk mengatasi ketidakpastian data dengan menggunakan formula bayes yang dinyatakan dengan rumus sebagai berikut [9][8]:

$$
P(A \mid B)=\frac{P(B \mid A) x P(A)}{P(B)}
$$

Dengan:

$\mathrm{P}(\mathrm{A} \mid \mathrm{B})$ : Probabilitas A dan B terjadi bersama-sama.

$\mathrm{P}(\mathrm{B} \mid \mathrm{A})$ : Probabilitas B dan A terjadi bersama-sama.

P(B): Probabilitas kejadian B. 
Teorema Bayes banyak dilakukan pada hal-hal yang berkenan dengan probabilitas serta kemungkinan dari penyakit dan gejala-gejala yang saling berkaitan. Teorema bayes juga dapat dilakukan pengembangan jika dilakukan sebuah pengujian terhadap hipotesis kemudian

muncul lebih dari sebuah evidence. Adapun bentuk dari teorema bayes untuk evidence tunggal E dan hipotesis ganda H1, H2, H3 ,..., Hn. Dalam hal ini maka persamaanya akan menjadi:

$$
P\left(H_{i} \mid E\right)=\frac{P\left(E \mid H_{i}\right) x P\left(H_{i}\right)}{\sum_{k=1}^{n} P\left(E \mid H_{k}\right)}
$$

Dengan:

$P\left(H_{i} \mid E\right)=$ Probabilitas hipotesis $\mathrm{H}_{\mathrm{i}}$ terjadi jika evidence $\mathrm{E}$ terjadi.

$P\left(E \mid H_{i}\right)=$ Probabilitas munculnya evidence $\mathrm{E}$, jika hipotesis $\mathrm{H}_{\mathrm{i}}$ terjadi.

$P\left(H_{i}\right)=$ Probabilitas hipotesis $\mathrm{H}_{\mathrm{i}}$ tanpa memandang evidence apapun.

$\mathrm{n}=$ Jumlah hipotesis yang terjadi.

\section{HASIL DAN PEMBAHASAN}

Pada penelitian ini akan dibahas tentang gejala dan pengobatan dari penyakit sifilis yang diakibatkan oleh bakteri treponema pallidum. Penelitian ini juga akan melakukan diagnosa penyakit dengan menggunakan teorema bayes sehingga hasil diagnosa memiliki nilai probabilitas yang dapat digunakan sebagai acuam dalam menentukan apakah pasien tersebut terkena penyakit sifilis atau tidak.

\subsection{Hasil}

Adapun hasil dari penelitian yang telah dilakukan adalah sebagai berikut:

1. Gejala dari Bakteri Treponema Pallidum

Setelah melakukan proses pengumpulan data dengan wawancara langsung dengan pakar dan studi literatur mengenai bakteri Treponema Pallidum, maka dapat dijabarkan gejala dari bakteri ini seperti pada tabel 1 sebagai berikut:

Tabel 1. Data Gejala Bakteri Treponema Pallidum

\begin{tabular}{|c|c|c|c|}
\hline No & Gejala & Bakteri & Pengobatan \\
\hline 1 & Muncul Luka Pada Kelamin atau Anus & \multirow{7}{*}{$\begin{array}{c}\text { Treponema } \\
\text { Pallidum }\end{array}$} & \multirow{7}{*}{$\begin{array}{l}\text { Penisilin dapat digunakan } \\
\text { untuk mengobati penyakit } \\
\text { sifilis. } \\
\text { Satu suntikan penisilin bisa } \\
\text { menghentikan perkembangan } \\
\text { penyakit jika Anda terinfeksi } \\
\text { kurang dari satu tahun. Untuk } \\
\text { infeksi yang berlangsung } \\
\text { lebih dari satu tahun, Anda }\end{array}$} \\
\hline 2 & $\begin{array}{l}\text { Muncul Luka Pada Bibir, Amandel, } \\
\text { atau Jari }\end{array}$ & & \\
\hline 3 & $\begin{array}{l}\text { Muncul Ruam Ditelapak Tangan dan } \\
\text { Kaki atau Bagian Tubuh Lainnya }\end{array}$ & & \\
\hline 4 & Muncul Kutil Pada Kelamin atau Anus & & \\
\hline 5 & $\begin{array}{l}\text { Timbul Rasa Lelah, Sakit Kepala, } \\
\text { Nyeri Sendi, Dan Demam }\end{array}$ & & \\
\hline 6 & Berat Badan Turun & & \\
\hline 7 & Rambut Rontok & & \\
\hline
\end{tabular}




\begin{tabular}{|l|l|l|l|}
8 & Kelenjar Limfa Bengkak & $\begin{array}{l}\text { mungkin perlu penambahan } \\
\text { dosis. }\end{array}$
\end{tabular}

2. Penyajian Fakta Dan Aturan

Penyajian fakta dan aturan untuk pendeteksian penyakit Sifilis diperoleh dari pengetahuan seorang pakar atau dokter dan melalui hasil observasi langsung ke klinik pengobatan penyakit yang disebabkan oleh bakteri Treponema Pallidum. Adapun fakta dan aturan tersebut telah dimuat ke dalam bentuk tabel sebagai berikut:

Tabel 2. Aturan

\begin{tabular}{|c|c|}
\hline No & Aturan (Rule) \\
\hline \multirow{4}{*}{1} & IF Gejala 1 is True \\
\hline & AND Gejala 2 is True \\
\hline & AND Gejala 3 is True \\
\hline & THEN Treponema Pallidum (Sifilis) \\
\hline \multirow{6}{*}{2} & IF Gejala 1 is True \\
\hline & AND Gejala 2 is True \\
\hline & AND Gejala 3 is True \\
\hline & AND Gejala 4 is True \\
\hline & AND Gejala 5 is True \\
\hline & THEN Treponema Pallidum (Sifilis) \\
\hline \multirow{8}{*}{3} & IF Gejala 1 is True \\
\hline & AND Gejala 2 is True \\
\hline & AND Gejala 3 is True \\
\hline & AND Gejala 4 is True \\
\hline & AND Gejala 5 is True \\
\hline & AND Gejala 6 is True \\
\hline & AND Gejala 7 is True \\
\hline & THEN Treponema Pallidum (Sifilis) \\
\hline \multirow{9}{*}{4} & IF Gejala 1 is True \\
\hline & AND Gejala 2 is True \\
\hline & AND Gejala 3 is True \\
\hline & AND Gejala 4 is True \\
\hline & AND Gejala 5 is True \\
\hline & AND Gejala 6 is True \\
\hline & AND Gejala 7 is True \\
\hline & AND Gejala 8 is True \\
\hline & THEN Treponema Pallidum (Sifilis) \\
\hline
\end{tabular}

3. Perhitungan Diagnosa Dengan Teorema Bayes

Diagnosa penyakit sifilis dengan teorema bayes dilakukan dengan beberapa tahapan. Tahapan-tahapan tersebut diperlukan untuk memperoleh hasil diagnosa dan perhitungan yang akurat. Adapun tahapan-tahapan dalam proses diagnosa dengan teorema bayes dapat dilihat pada gambar 2 sebagai berikut. 


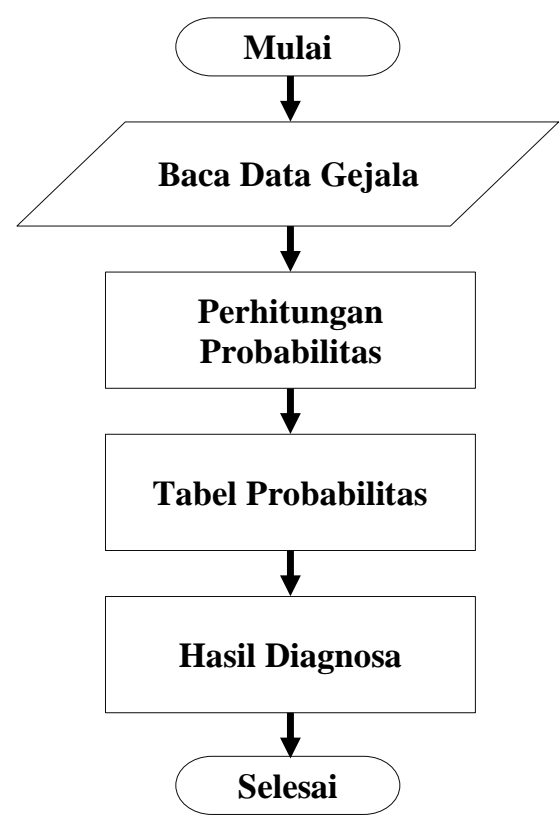

Gambar 2. Flowchart Teorema Bayes

Sebelum melakukan perhitungan dengan metode teorema bayes, terlebih dahulu harus menentukan nilai densitas dari setiap gejala terhadap penyakit dari akibat bakteri treponema pallidum. Nilai densitas dari masing-masing gejala ditunjukkan pada tabel 3 sebagai berikut:

Tabel 3. Nilai Densitas Gejala

\begin{tabular}{|c|l|c|}
\hline Kode Gejala & \multicolumn{1}{|c|}{ Gejala } & Nilai Densitas \\
\hline G01 & Muncul Luka Pada Kelamin atau Anus & 0.8 \\
\hline G02 & Muncul Luka Pada Bibir, Amandel, atau Jari & 0.8 \\
\hline G03 & $\begin{array}{l}\text { Muncul Ruam Ditelapak Tangan dan Kaki atau Bagian } \\
\text { Tubuh Lainnya }\end{array}$ & 0.7 \\
\hline G04 & Muncul Kutil Pada Kelamin atau Anus & 0.9 \\
\hline G05 & $\begin{array}{l}\text { Timbul Rasa Lelah, Sakit Kepala, Nyeri Sendi, Dan } \\
\text { Demam }\end{array}$ & 0.6 \\
\hline G06 & Berat Badan Turun & 0.5 \\
\hline G07 & Rambut Rontok & 0.6 \\
\hline G08 & Kelenjar Limfa Bengkak & 0.7 \\
\hline
\end{tabular}

Setelah dilakukan perhitungan dengan teorema bayes terhadap beberapa gejala dari bakteri treponema pallidum diperoleh hasil sebagai berikut:

Tabel 4. Hasil Diagnosa Terhadap Beberapa Gejala

\begin{tabular}{|c|c|c|}
\hline Jumlah Gejala & Hasil Perhitungan & Persentase \\
\hline 3 Gejala & 0,772316 & $0,77 \%$ \\
\hline 5 Gejala & 0,786395 & $0,79 \%$ \\
\hline 7 Gejala & 0,747324 & $0,75 \%$ \\
\hline 8 Gejala & 0,741584 & $0,74 \%$ \\
\hline
\end{tabular}




\subsection{Pembahasan}

Berdasarkan perhitungan yang telah dilakukan terhadap beberapa gejala diperoleh hasil diagnose dengan lima (5) gejala lebih tinggi yaitu dengan nilai 0,79\% dibandingkan dengan hasil diagnosa dengan jumlah gejala lainnya. Hal ini disebabkan karena lima gejala awal ini merupakan gejala inti yang memiliki nilai densitas tinggi, sementara tiga gejala lainnya tersebut merupakan gejala pendukung yang memiliki nilai densitas rendah. Namun semua hasil perhitungan masih dapat digunakan untuk mendiagnosa penyakit yang diakibatkan oleh bakteri Treponema Pallidum karena berdasarkan table nilai probabilitas bayes nilai $70 \%$ ke atas memiliki probabilitas PASTI. Hal ini diketahui berdasarkan tabel probabilitas yang dimiliki oleh teorema bayes seperti terlihat pada tabel 5 sebagai berikut:

Tabel 5. Probabilitas Teorema Bayes

\begin{tabular}{|c|c|}
\hline Nilai Probablitas Bayes & Theorema Bayes \\
\hline $0-0.2$ & Tidak Ada \\
\hline $0.3-0.4$ & Mungkin \\
\hline $0.5-0.6$ & Kemungkinan Besar \\
\hline $0.7-0.8$ & Pasti \\
\hline $0.9-1$. & Sangat Pasti \\
\hline
\end{tabular}

\section{KESIMPULAN}

Berdasarkan penelitian dan pembahasan yang dilakukan, maka dapat disimpulkan bahwa bakteri treponema pallidum dapat menyebabkan penyakit sifilis atau raja singa. Penyakit ini dapat menyebabkan komplikasi bahkan kematian jika penyakit ini sudah dalam tahap buruk atau mengkhawatirkan. Teorema bayes dapat digunakan untuk menghitung nilai probabilitas dari bakteri treponema pallidum berdasarkan nilai densitas dari gejala yang ada. Hasil perhitungan menunjukkan bahwa teorema bayes memberikan nilai tertinggi yaitu $79 \%$ untuk lima gejala utama, dan memberikan nilai terendah $74 \%$ untuk perhitungan seluruh gejala yang ada.

\section{SARAN}

Sebagai akhir dari penelitian ini, peneliti ingin menyampaikan saran-saran yang mungkin bermanfaat bagi siapa saja yang berminat untuk mengembangkan penelitian ini.

1. Membuat aplikasi sistem pakar yang dapat mendiagnosa penyakit yang diakibatkan oleh bakteri treponema pallidum menggunakan teorema bayes.

2. Untuk mendapakan hasil perbandingan diagnosa sebaiknya diterapkan metode-metode probabilitas lainnya.

\section{DAFTAR PUSTAKA}

[1] D. Yulyanti, A. Novilla, and G. Khairinisa, "Gambaran Infeksi Sifilis pada Komunitas Biseksual Menggunakan Metode Treponema Pallidum Haemaglutination As say ( TPHA )," 1st Proceeding Publ. Creat. Res. Med. Lab. Technol. DIV, vol. 1, no. 1, pp. 1-4, 2019.

[2] I. Effendi, "Pemeriksaan Molekular Treponema pallidum," J. Kedokt Meditek, vol. 24, no. $68,2018$.

[3] F. Rachmawati, "Treponema pallidum Resisten Makrolida: Review," 1st Proceeding Publ. Creat. Res. Med. Lab. Technol. DIV, vol. 1, no. 1, pp. 98-101, 2019. 
[4] Y. Arisanti, R. Tanjung, and V. D. Cahyani, "Gambaran Umum Kasus Frambusia Setelah Pengobatan Massal dengan Azitromisin di Kota Jayapura," Bul. Penelit. Kesehat., vol. 47, no. 2, pp. 77-82, 2019.

[5] H. Sinaga and T. A. Said, "Hasil Pemeriksaan Treponema pallidum Haemagglutination Assay dan Treponema pallidum Rapid pada Penderita Sifilis di Balai Laboratorium Kesehatan Provinsi Papua," J. Penelit. Kesehat. Suara Forikes, vol. 10, no. 2, pp. 88-92, 2019.

[6] N. S. B. Sembiring and M. D. Sinaga, "Penerapan Metode Dempster Shafer Untuk Mendiagnosa Penyakit Dari Akibat Bakteri Treponema Pallidum," CSRID J., vol. 9, no. 3, pp. 180-189, 2017.

[7] N. Rosmawanti and G. P. Kusumawardhani, "MODEL SISTEM PAKAR DIAGNOSA PENYAKIT GAGAL GINJAL MENGGUNAKAN METODE TEOREMA BAYES," JUTISI, vol. 9, no. 3, 2020.

[8] F. A. Sianturi, "Analisa metode teorema bayes dalam mendiagnosa keguguran pada ibu hamil berdasarkan jenis makanan," J. TEKINKOM, vol. 2, no. 1, pp. 87-92, 2019.

[9] P. S. Ramadhan and Tugiono, "Sistem e-pediatric untuk pendiagnosaan eflorsen dermatis menggunakan teorema bayes," SEBATIK, pp. 242-247, 2019.

[10] F. Bangun and J. R. Sagala, "SISTEM PAKAR MENDIAGNOSA PENYAKIT TBC MENGGUNAKAN METODE TEOREMA BAYES," J. Tek. Dan Inform., vol. 6, no. 2, 2019.

[11] R. Rachman and S. Moritami, "Sistem Pakar Deteksi Penyakit Refraksi Mata Dengan Metode Teorema Bayes Berbasis Web," J. Inform., vol. 7, no. 1, pp. 68-76, 2020.

[12] N. Sulardi and A. Witanti, "SISTEM PAKAR UNTUK DIAGNOSIS PENYAKIT ANEMIA MENGGUNAKAN TEOREMA BAYES," J. Tek. Inform., vol. 1, no. 1, pp. 19-24, 2020. 